Стана Смиљковић

Педагошки факултет у Врању
821.163.41.09-94

94(100)"1914/1918"

https://doi.org/10.18485/melissa.2017.16.1.ch3

\title{
ИМАГИНАРНИ СВЕТОВИ РАТНИКА ИЛИ БЕКСТВО ОД СТВАРНОСТИ*
}

Насловљен као Ратни дневник аутора Миодрага В. Петровића није у правом смислу дневничка проза или забелешке о рату. То је један назначен свет у коме много више доминира уметнички ликовно-текстуално поетски низ, слике о страдању, патњи, жељи да се успе, иако је младим војницима смисао борбе, погибије, жртвовања прилично нејасан. Зато и беже у сан на јави: „Дан, сунце, обала каменита. Море мирно зелено плавкасто. Једна стена дубоко ушла у море, чији се рефлекс игра са малим таласићима. Наш војник окупао се, у пола се обукао и изашао на стену да у хладу смокве, мало продрема. Море пева. Из њега измилеле пет нимфе, окружују га, смеју се и једна га сламком шашољи по лицу. Закићене коралом и морским цвећем..." (76)

Забелешке аутора по својим метафорично-симболичним сликама могу се сврстати у списак песама у прози, а спискова и низова мисли војника, посматрача, учесника ратних збивања и предаха, као и скице њихових портрета са маркантним детаљима и наговештајима покрета, говоре о спремности да и на тај начин њихов портрет заузме место које му одговара. Шкрт израз, богатство значења, краткоћа описа, спој атмосфере на земљи и атмосфере у географском поимању, делује мистично у реалном окружењу, а то све обогаћује изворе уметничког значења.

Наизглед, све је мирно у природи. Снажна бура је у душама људи која подстиче борбу у себи и са собом. Ипак, у очекивању тишине виде сопствено спасење: „Крај морске обале, на Крфу стоји наш

Ратни дневник Миодрага В. Петровића, приредила Александра Вранеш, Андрићев институт, Андрићград, 2015. 
војник и гледа преко пушке пут Србије. Замишљен, тужан. Позади њега се дижу црни кипариси. Подне. Сунце у највећем јеку сија. Обала песковита до које допиру ситни таласићи“ (73). Нема бунта. Има наде. Искуство ратника и јединствено искуство аутора исказано кратким хаику реченицама или стиховима потврђују мисао да је човеков живот пун неизвесности.

\section{Свет изван светова}

Књигу Ратни дневник прожима јединствена идеја - бесмисленост ратовања, смрт као догађај који је очекиван, освајање неизвесних даљина, сусрети са морским плаветнилом у коме се види спас од смрти, или живота. Структура текста и слике доживљена у свести или мисли аутора, као и визуелни трик, све су то елементи који се претачу у доживљај у ширем значењу речи. Али, како истиче Иво Андрић „ток догађаја у животу не зависи од нас, или врло мало, али начин на који ћемо догађаје поднети зависи у доброј мери од нас самих. На то треба трошити снагу и обраћати пажњу."

У најтежим тренуцима, српски ратници воде драматичне битке, не само против непријатеља, већ и да мисао и свест задрже како би нашли привидни мир у хаосу. Препуштени себи и остављенима далеко од себе, присећају се сцена из давно прочитаних бајки, митова, легенди. У таквим ситуацијама они постају сасвим друга бића: халуцинирају и „виде“ оно што ће им за трен улепшати сан о срећи. Појава чудесних бића-нимфи, водених вила и других измаштаних створења оживљавају традицију и митологију која их је у домовини пратила. Текст своју смисленост пројектује кроз слику, или обрнуто. Зато на слици живи ратници ретко када седе. Усправни положај симболизује немирење са тешкоћама. Такве су и чудесне морске појавности: „Лађа се потопила. Један наш војник, пливајући, спасао се на обалу и онесвестио се. Сирене га нашле и хоће да му помогну. Он долази себи. Чуди се, трза се, оне озбиљне, дижу га. На њему је обруч за спасавање“ (154). У тренуцима кризе, самоће, глади, болести, халуцинантне сцене откривају подсвест младих људи, њихове страсти, недоживљене тренутке лепоте. Зато они, и кад је све на из- 
маку, и када се испред њих непрекидно виде планине и непроходни путеви као непремостиве препреке, бојама у сновима остварују живот себи својствен. „Неколико официра и војника возају се чамцем по мору. Први сутон. Небо на западу још врло мало румено - иначе плаво зеленкасто. Месец увелико сија, али се на слици не види, само његов рефлекс игра по мирној пучини. По целом мору просула се маса фосфорних тачкица. Чамац полако сам плови, без једара, весла опуштена" (88).

Спој визуелног и текстовног, наговештаји звукова, поремећаји тишине спуштањем погинулих у море, тихе молитве које прате њихов одлазак из света живих, бела пена која се појави и нестане са њима, све то појачава тугу, боји је у зависности од ситуације и тренутка. Експресивна снага слике и текста у њој упућује на вишезначност исказаног, допушта домишљање, неко ново стварање, баш као што то чини неименовани српски војник као „Нови Одисеј“: „Спасао се на усамљено острво - каменито. Он сам и нимфа. Српски војник у подераном летњем оделу, без ципела, сео на стену и сањалачким погледом блуди пут отаџбине - Србије. Нимфа у харфу, направљеној од дрвета, више њега стојећи свира и пева веселе арије не би ли му мисли ма колико развеселила. Море мирно, дан јасан. Позади у камењару пећина“ (110).

Туга војника, у ретким тренуцима, проткана је и прошарана ироничним хумором којим ће се за трен одагнати бол и самоћа. Ауторова спретност да у најтежим тренуцима животног искушења угради и хумористичне сцене, указује на посебну врсту комуникације са светом. Овакве сцене настају из неспоразума са другим језиком, неспретно изговорених речи, чуђења другој култури и традицији, првог виђења мора и пустиње, понашања у болници. Иако у групи, у војничким стројевима или болесничким собама, нема посебне комуникације или исповести. Углавном су њихове мисли сажете у само њима доступне монологе. Они живе са својим тегобама и страхотама, а да притом реч страх не помену ни у најтежој ситуацији, иако она лебди и изазива сумњичавост. У свом лутању у мислима, одвојен од стварности одлази пут извора: „Војник пошао са чутурицама да нађе извор и за десетину донесе воду. Наишао на вилино врело. Виле га ухва- 
тиле. Посадиле на камен крај извора и смеју се. Скинуле му шлем и од цвећа му праве венац око главе. Све се смеју. Војник зачуђен, озбиљан, мало уплашен, сео на камен као свећа. Једна му скида чутурице са рамена да му их напуни“ (143). Слика, звук и знак јасно указују на растрзаност мисли, бојазан од самоће у туђини, немирење са судбином. Игра мисли сједињена је са имагинарним халуцинантним играма вила крај извора. Извор као симбол живота, вода која као огледало одражава лик, враћа посусталу снагу усамљеном војнику. И кад му је најтеже, он жели ужитак. Ту је венчић који замењује шлем. Ту је повратак детињству и родном крају.

\section{„Испод маслине види се зелено море“}

Узајамна веза између текста и слике, прожимање линија и текста, потеза и боја са одабраним везама речи шкртог израза, боје без текста и текст без скица - у потпуности откривају атмосферу и људе различитих схватања и виђења живота у њој. Сусрети са туђином и становницима друге вере и језика, менталитета, друге и древне културе - проширују сазнања српских војника. Њихова радозналост да упознају, и у тешким тренуцима, други свет, географске пределе, навике, начин одевања и живота у пустињским пределима, представља ново искуство које ће њима, и њиховим потомцима, значити у животу, уколико преживе ратне суровости и болести.

Аутор је кроз мисли, снове, жеље, чежње и разговоре, слике у основним контурама, сенке предела, осветлио њихову психологију. Тегобе на које наилазе и туга коју осећају сахрањујући и остављајући другове испод снегова у албанским гудурама, парају њихова срца. Свесни су да животна неизвесност лебди, и поред тога што у њиховим грудима бију дамари који их вуку напред. Сивило, глад, болести, напади непријатеља, напор на путу, сусрети са непознатим, ретко хуманим људима - све су то искушења која аутор исписује и ликовним траговима дочарава паћенике. И поред свега, њихова осећања нису отупела: „Кроз шуму наступа стрељачки строј. Две шумске виле виде га из далека, уплаше се и крију се иза камења. Подне. Дан јасан. Шума густа, влажна. Ипак, сунце се пробија кроз лишће и игра по земљи и нагим телима вила“ (153). 
Драма у младим срцима кроз симболични сусрет у тренуцима потпуне одсутности од стварности, виде фигуре вила и нимфи, бајковите личности које су се задржале у њиховим мислима из доживљаја детињега живота.

Ликовно и текстовно поље које представља ауторову концепцију и структуру у једнакој мери чини јединство. Интелектуално и морално прозборило је из ликова ратника и аутора који је и сам свевидећи ратни путник, што указује на биографску црту ове некласичне лирске творевине. Способност опажања значајних момената живота у ратним условима, омогућила је да сликом и текстом створи драмски ефекат, да кратке разговоре преслика и тако створи посебну врсту отвореног дела спајајући стрелице једне и друге уметности, преносећи значење једног и другог медија у целовити, али афористички склоп. Једном речју, унутрашња скала осећања учесника ратне драме и реципијената, како данас, тако и убудуће тумачиће се, како каже и Егзипери „за нас се животна вредност не налази у спољашњим околностима, већ у начину на који се ми с њима суочавамо“. Тако је писац - сликар кроз ликовне и текстовне минијатуре усредсредио своју пажњу на тематику рата у реалном окружењу, и тематику визије будућности - неизвесне, као што је и његово дело до сада живело у неизвесности, али у трајању. 